\title{
Performance of Dairy Cows Fed Annual Ryegrass Silage and Corn Silage with Steam-Flaked or Ground Corn
}

\author{
K. M. Cooke, J. K. Bernard, ${ }^{1}$ and J. W. West \\ Department of Animal and Dairy Science, University of Georgia, Tifton 31793-0748
}

\section{ABSTRACT}

Twenty-four lactating Holstein cows were used in a 6 -wk randomized block design trial with a $2 \times 2$ factorial arrangement of treatments to determine the effects of feeding ground corn (GC) or steam-flaked corn (SFC) in diets based on either annual ryegrass silage (RS) or a 50:50 blend of annual ryegrass and corn silages (BLEND). Experimental diets contained $49.6 \%$ forage and were fed as a total mixed ration once daily for 4 wk after a 2-wk preliminary period. No interactions were observed among treatments. Cows fed BLEND consumed more dry matter (DM), organic matter (OM), neutral detergent fiber (NDF), and acid detergent fiber (ADF) than those fed RS, but total-tract digestibility of $\mathrm{OM}, \mathrm{NDF}$, and ADF was greater for RS than for BLEND. No differences in nutrient intake were observed among treatments during wk 4 when nutrient digestibility was measured, but digestibility of DM and OM was greater for SFC than for GC. Cows fed BLEND tended to produce more energy-corrected milk than those fed RS, resulting in improved efficiency ( $\mathrm{kg}$ of milk per $\mathrm{kg}$ of DM intake). When diets were supplemented with SFC, cows consumed less DM and produced more milk that tended to have lower milk fat percentage. Yield of milk protein and efficiency was greatest with SFC compared with GC. Blood glucose and milk urea nitrogen concentrations were similar among treatments, but blood urea nitrogen was greater for cows fed GC compared with those fed SFC. Results of this trial indicate that feeding a blend of annual ryegrass and corn silage is more desirable than feeding diets based on RS as the sole forage. Supplementing diets with SFC improved performance and efficiency compared with GC across forage sources.

Key words: ryegrass silage, corn silage, steam-flaked corn, ground corn

Received September 21, 2007.

Accepted February 25, 2008

${ }^{1}$ Corresponding author: jbernard@uga.edu

\section{INTRODUCTION}

Annual ryegrass silage (RS) is frequently used as a forage source in the diets of lactating dairy cows. Annual ryegrass has moderate to high concentrations of nitrogen and the fiber is highly digestible when harvested in a vegetative stage of maturity. Much of the nitrogen in RS is soluble or is readily degraded in the rumen (Van Vuuren et al., 1990). Previous research indicates that blending corn silage and grass or legume silage increases yield of milk and components (Keys et al., 1984) and improves nitrogen utilization and feed cost (Dhiman and Satter, 1997). Including feeds that contain high concentrations of fermentable carbohydrates (such as the grain in corn silage) improves nitrogen utilization by reducing ruminal $\mathrm{NH}_{3} \mathrm{~N}$ and urinary nitrogen excretion (Van Vuuren et al., 1993). McCormick et al. (1990) reported that RS could support similar DMI and milk yield as corn silage. Bernard et al. (2002) observed that as RS was substituted for 0,35 , 65 , and $100 \%$ of the forage DM provided by corn silage, yields of milk, fat, protein, and ECM increased linearly. These researchers also reported linear increases in fiber intake as the proportion of RS increased, which would improve ruminal starch digestion providing additional energy for microbial protein synthesis that supported increased yields of milk and milk components.

Annual ryegrass silage does not provide adequate energy to support high levels of milk yield, so supplemental energy is required. Although corn silage provides a source of readily fermentable carbohydrate from the grain portion of the silage, additional concentrate may be beneficial to increase the supply of readily fermentable carbohydrate to the rumen to support microbial protein synthesis and milk production when feeding a blend of RS and corn silages. Ground corn (GC) is commonly used in the rations of lactating dairy cows and is an excellent source of readily fermentable carbohydrate. Steam-flaked corn (SFC) is highly digestible in the rumen due to the denaturation of the protein matrix of the starch granule. Denaturation of the matrix increases surface area and allows for greater microbial attachment and digestion of the starch granule, increasing energy available for microbial protein syn- 
thesis and increasing utilization of recycled and dietary nitrogen (Theurer et al., 1999). The net result to the animal is greater energy and microbial protein availability to support milk production. Cows fed diets containing steam-flaked corn produced more milk and gained more weight compared with cows fed steamrolled corn (Santos et al., 1999). However, most of the research with steam-flaked corn has been conducted using alfalfa hay as the principal forage. The objective of this study was to determine the effects feeding a blend of corn and ryegrass silages compared with ryegrass silage alone with 2 different energy sources on nutrient intake and digestibility and lactation performance in lactating dairy cows.

\section{MATERIALS AND METHODS}

Corn (Agratech 787, Agra Tech Seeds Inc., Ashburn, GA) was planted in a Tifton sandy loam soil at a seeding rate of approximately 69,135 plants per hectare. A commercial fertilizer was applied at the rate of $65 \mathrm{~kg}$ of $\mathrm{N}$, $65 \mathrm{~kg}$ of $\mathrm{P}$, and $126 \mathrm{~kg}$ of $\mathrm{K}$ per ha immediately before planting. An additional $108 \mathrm{~kg}$ per ha of $\mathrm{N}$ was applied when the corn was approximately $60 \mathrm{~cm}$ in height. Corn was irrigated with dairy waste effluent to provide nutrients with additional fresh water to meet water requirements. Corn was chopped using a conventional pulltype forage chopper and stored in a concrete stave silo. Annual ryegrass (Marshall) was planted at the rate of $50.4 \mathrm{~kg}$ per ha in Tifton sandy loam soil. Fertilizer was applied at the rate of $54 \mathrm{~kg}$ of N, $13 \mathrm{~kg}$ of $\mathrm{P}$, and $27 \mathrm{~kg}$ of $\mathrm{K}$ per ha immediately before planting. An additional $57 \mathrm{~kg}$ of $\mathrm{N}$ per ha was applied in late winter. Ryegrass in the late vegetative stage of maturity was mown and allowed to wilt to approximately $40 \%$ DM before being chopped and packed in a $2.4-\mathrm{m}$ plastic silage bag until the lactation trial.

Twenty-four Holstein cows (186 \pm 66 DIM, $34.0 \pm 6.7$ $\mathrm{kg} / \mathrm{d}$ milk, and $589 \pm 57 \mathrm{~kg}$ of BW) were used in a 6 -wk randomized block design trial with a $2 \times 2$ factorial arrangement of treatments. All protocols were reviewed and approved by the University of Georgia Institute of Animal Care and Use Committee. The trial consisted of a 2-wk standardization period followed by a 4 -wk experimental period. Cows were blocked by ECM and randomly assigned to treatments. Treatments included 2 forages (100\% RS or a 50:50 blend of RS and corn silage; BLEND) and 2 energy supplements (GC or $\mathrm{SFC})$. The SFC was prepared at a local mill to a density of $0.36 \mathrm{~kg} / \mathrm{L}$ (South Georgia Grain Services, Albany, GA). Experimental diets (Table 1) contained $49.6 \%$ forage and were formulated to contain equal concentrations of CP, NDF, and energy. Cows were fed a TMR once daily $(0800 \mathrm{~h})$ behind Calan doors (American Ca-
Table 1. Composition of experimental diets containing either ryegrass silage (RS) or a combination of ryegrass and corn silage (BLEND) supplemented with either ground (GC) or steam-flaked corn (SFC)

\begin{tabular}{|c|c|c|c|c|}
\hline \multirow[b]{2}{*}{ Item } & \multicolumn{2}{|c|}{$\mathrm{RS}$} & \multicolumn{2}{|c|}{ BLEND } \\
\hline & GC & $\mathrm{SFC}$ & GC & $\mathrm{SFC}$ \\
\hline & & $-\% 0$ & $\mathrm{DM}$ & \\
\hline \multicolumn{5}{|l|}{ Ingredient } \\
\hline Corn silage & 0.0 & 0.0 & 24.8 & 24.8 \\
\hline Ryegrass silage & 49.6 & 49.6 & 24.8 & 24.8 \\
\hline Ground corn & 32.8 & - & 24.9 & - \\
\hline Steam-flaked corn & - & 32.8 & - & 24.9 \\
\hline Whole cottonseed & 9.8 & 9.8 & 9.8 & 9.8 \\
\hline Megalac $^{1}$ & 0.9 & 0.9 & 0.9 & 0.9 \\
\hline Soybean meal, $48 \% \mathrm{CP}$ & 0.7 & 0.7 & 7.4 & 7.4 \\
\hline Prolak $^{2}$ & 3.5 & 3.5 & 3.5 & 3.5 \\
\hline Dicalcium phosphate & 0.1 & 0.1 & 0.2 & 0.2 \\
\hline Limestone & 0.9 & 0.9 & 1.0 & 1.0 \\
\hline Potassium carbonate & - & - & 1.0 & 1.0 \\
\hline Trace mineral-vitamin premix ${ }^{3}$ & 1.8 & 1.8 & 1.8 & 1.8 \\
\hline \multicolumn{5}{|l|}{ Chemical composition } \\
\hline $\mathrm{DM}$ & 52.2 & 52.1 & 51.8 & 50.7 \\
\hline Ash & 18.4 & 18.3 & 14.8 & 14.8 \\
\hline $\mathrm{CP}$ & 18.9 & 18.5 & 18.6 & 18.3 \\
\hline $\mathrm{ADF}$ & 21.5 & 21.8 & 19.6 & 19.8 \\
\hline NDF & 30.6 & 30.9 & 30.0 & 30.3 \\
\hline $\mathrm{NFC}^{4}$ & 29.0 & 29.2 & 33.5 & 33.7 \\
\hline $\mathrm{NE}_{\mathrm{L}},{ }^{4} \mathrm{Mcal} / \mathrm{kg}$ & 1.68 & 1.65 & 1.70 & 1.70 \\
\hline
\end{tabular}

${ }^{1}$ Calcium salts of long-chain fatty acids $(84.5 \%$ fatty acids and $15.5 \%$ ash, DM basis); Church and Dwight Co., Inc. (Princeton, NJ).

${ }^{2} \mathrm{Blend}$ of marine, poultry, and porcine proteins $(79 \% \mathrm{CP}, 6.6 \%$ fatty acids, and $10.8 \%$ ash, DM basis); H. J. Baker and Bro., Inc. (Stamford, CT).

${ }^{3}$ Premix contained (DM basis) $99.07 \%$ of ash; $14.27 \%$ of Ca; $5.42 \%$ of P; $4.96 \%$ of $\mathrm{Mg} ; 0.05 \%$ of $\mathrm{K} ; 10.67 \%$ of $\mathrm{Na} ; 2.98 \%$ of $\mathrm{Cl} ; 0.37 \%$ of $\mathrm{S} ; 11 \mathrm{mg} / \mathrm{kg}$ of Co; $577 \mathrm{mg} / \mathrm{kg}$ of Cu; $4,858 \mathrm{mg} / \mathrm{kg}$ of Fe; $51 \mathrm{mg} / \mathrm{kg}$ of I; $1,806 \mathrm{mg} / \mathrm{kg}$ of $\mathrm{Mn} ; 13 \mathrm{mg} / \mathrm{kg}$ of Se; $1,694 \mathrm{mg} / \mathrm{kg}$ of Zn; $115,240 \mathrm{IU} /$ $\mathrm{kg}$ of vitamin A; 46,100 IU/kg of vitamin D; and $576 \mathrm{IU} / \mathrm{kg}$ of vitamin E.

${ }^{4}$ Calculated using forage and energy supplement analysis and NRC (2001) values.

lan, Northwood, NH) in amounts to provide approximately $10 \%$ orts for ad libitum consumption. Amount of TMR offered and refused was recorded daily. Cows were milked twice daily at approximately 0400 and $1500 \mathrm{~h}$, and daily milk yield was recorded electronically (Alpro, DeLaval, Kansas City, MO).

\section{Sample Collection and Analysis}

Milk samples were collected from consecutive p.m. and a.m. milkings once each week of the trial. Milk samples were shipped to Southeast Dairy Laboratory (McDonough, GA) for analyses of fat, protein, and MUN using a Foss 4000 equipped with an A filter (Foss North America, Eden Prairie, MN; AOAC, 1990).

Experimental diets, treatment silages, energy supplements, and orts were collected 3 times each week. Samples were composited each week of the trial and 
dried at $55^{\circ} \mathrm{C}$ for $72 \mathrm{~h}$ and ground to pass through a 1-mm screen using a Wiley mill (Arthur H. Thomas, Philadelphia, PA). The DM content of forages was determined according to Goering and Van Soest (1970) and all other samples according to AOAC (1990). All samples were analyzed for N (Leco FP-528 Nitrogen Analyzer, St. Joseph, MI), ADF, and NDF (Van Soest et al., 1991).

During wk 4 of the experimental period, fecal grab samples were collected from each cow on 4 consecutive days at 12 -h intervals. Sampling time was advanced by $2 \mathrm{~h}$ each day so that samples were collected at 0500 , $0700,0900,1100,1700,1900,2100$, and 2300 h. Samples were composited by cow and dried in a forced-air oven at $60^{\circ} \mathrm{C}$ for $72 \mathrm{~h}$. Samples were ground to pass through a 1-mm screen using a Wiley mill and analyzed for $\mathrm{DM}, \mathrm{CP}, \mathrm{ADF}$, and $\mathrm{NDF}$ as described previously. Diet, ort, and fecal samples were analyzed for indigestible ADF as an internal marker as described by Cochran et al. (1986). Nutrient intake and digestibility was calculated using DMI for wk 4 and chemical analysis of diets and fecal samples.

Body weights were recorded on 2 consecutive days at the end of the standardization period and wk 4 of the experimental period. To minimize variation, BW was recorded after the p.m. milking before animals had access to feed or water. Whole blood samples were collected via coccygeal venipuncture during the standardization period and during wh 4 approximately $4 \mathrm{~h}$ after feeding. Tubes were allowed to clot, and serum was harvested by centrifugation. Samples were analyzed at the University of Georgia Veterinary Diagnostic Laboratory in Tifton for BUN and glucose using a Boehringer Mannheim/Hitachi 912 automated chemistry analyzer (Roche Laboratory Systems, Indianapolis, IN).

\section{Statistical Analysis}

Analyses of covariance of production data, which included repeated measures, were conducted using PROC MIXED procedures of SAS (SAS Institute, 2001). Sums of squares were partitioned to covariate, DIM at the beginning of the trial, block, forage, energy supplement, week, and the appropriate interactions. Pretrial variables were used as covariates in each of the respective models. Cow within treatment was included as a random variable and week was considered a repeated measure.

\section{RESULTS AND DISCUSSION}

\section{Chemical Composition}

Experimental diets contained similar concentrations of $\mathrm{CP}$ and NDF (Table 1). The BLEND diet contained slightly lower concentrations of $\mathrm{ADF}$ and slightly greater concentrations of NFC compared with the RS diet reflecting the lower fiber and greater starch concentrations of the corn silage in the BLEND. Average concentration of DM, CP, and NDF for experimental diets was $51.7,18.6$, and $30.5 \%$ of DM, respectively. Concentrations of NDF were slightly lower than planned but were adequate to maintain rumen function. The ryegrass silage (Table 2 ) contained slightly greater concentrations of CP and more ash than reported by NRC (2001). The high ash concentration observed for the annual ryegrass is related to the sandy nature of the soil. Because of the greater ash content of the ryegrass silage, the ash content was slightly greater for the RS vs. the BLEND diets. The fiber concentrations were lower than that reported for cool-season grasses by NRC (2001), but were consistent with material harvested at this stage of maturity at our location. The chemical composition of GC and SFC were similar.

\section{Nutrient Intake and Digestibility}

Nutrient intake and apparent whole-tract digestibility data measured during wk 4 are presented in Table 3 . No interactions were observed among forage and concentrate sources. Intake of DM $(P=0.006), \mathrm{OM},(P=$ $0.002), \operatorname{NDF}(P=0.008)$, and $\operatorname{ADF}(P=0.05)$ was greater for BLEND than for RS. Burke et al. (2007) reported increased DMI when corn silage replaced $33 \%$ of the forage DM supplied by perennial ryegrass silage compared with ryegrass as the sole forage source. Van $\mathrm{Vu}$ uren et al. (1999) reported increased intake and flow of OM to the duodenum when additional starch was fed to cows consuming diets based on grass silage. However, Bernard et al. (2002) observed no change in DMI, but greater intakes of NDF and ADF when ryegrass replaced corn silage at $0,35,65$, or $100 \%$ of the forage DM. The increased fiber intake in that study was related to the greater $\mathrm{NDF}$ and $\mathrm{ADF}$ concentrations in ryegrass compared with corn silage. In the current study, ADF concentrations were lower for BLEND (19.7\%) compared with RS (21.7\%), whereas NDF concentrations were similar between the 2 forages (30.8 vs. $30.2 \%$, respectively). Nutrient intake was not affected by source of corn.

Whole-tract digestibility of $\mathrm{OM}(P=0.05), \mathrm{NDF}(P=$ $0.02)$, and $\operatorname{ADF}(P=0.002)$ was greater for RS than for BLEND. Decreased DMI slows rumen passage rate allowing for greater nutrient digestibility (Moe et al., 1965). Hoffman et al. (1998) reported decreased passage rates and increased rumen retention times when cows were fed diets based on perennial ryegrass silage compared with alfalfa silage. Others (Broderick et al., 2002) have reported similar responses in nutrient digestibil- 
Table 2. Chemical composition of forages and grains

\begin{tabular}{lcccc}
\hline Item & Ryegrass silage & Corn silage & Ground corn & Steam-flaked corn \\
\hline $\mathrm{DM}$ & $38.1 \pm 5.3$ & $31.8 \pm 2.5$ & $90.8 \pm 1.0$ & $91.0 \pm 1.0$ \\
\cline { 2 - 3 } & $20.3 \pm 1.0$ & $8.5 \pm 0.0$ & $9.8 \pm 0.1$ & $8.5 \pm 0.6$ \\
$\mathrm{CP}$ & $28.6 \pm 1.5$ & $5.3 \pm 0.2$ & $1.6 \pm 0.1$ & $1.3 \pm 0.1$ \\
$\mathrm{Ash}$ & $32.3 \pm 0.2$ & $25.0 \pm 1.2$ & $3.8 \pm 0.6$ & $4.9 \pm 0.8$ \\
$\mathrm{ADF}$ & $43.6 \pm 0.3$ & $41.9 \pm 2.2$ & $10.7 \pm 0.3$ & $11.5 \pm 1.1$ \\
$\mathrm{NDF}$ & $0.40 \pm 0.02$ & $0.20 \pm 0.01$ & $0.02 \pm 0.02$ & $0.01 \pm 0.00$ \\
$\mathrm{Ca}$ & $0.46 \pm 0.10$ & $0.28 \pm 0.00$ & $0.31 \pm 0.01$ & $0.25 \pm 0.25$ \\
$\mathrm{P}$ & $0.21 \pm 0.01$ & $0.19 \pm 0.01$ & $0.10 \pm 0.01$ & $0.09 \pm 0.00$ \\
$\mathrm{Mg}$ & $4.81 \pm 0.26$ & $1.29 \pm 0.05$ & $0.47 \pm 0.03$ & 0.02 \\
$\mathrm{~K}$ & & &
\end{tabular}

ity when comparing perennial ryegrass with alfalfa. As previously stated, DMI for BLEND was greater compared with RS alone, which indicates a possible increase in rumen retention time and decreased passage rate and may explain the greater nutrient digestibility for cows fed RS. The amount of OM digested in the whole tract was approximately $1 \mathrm{~kg}$ greater for BLEND compared with RS, which may reflect additional digestion of starch provided by the corn silage. However, the amount of NDF digested in the whole tract was similar for both RS and BLEND.

Whole-tract digestibility of DM $(P=0.04)$ and $\mathrm{OM}$ $(P=0.03)$ was greater for SFC compared with GC. Although OM intake was similar, the greater OM digestibility observed with BLEND would have resulted in 1 $\mathrm{kg} / \mathrm{d}$ more OM digested, which presumably would provide additional energy in support of milk synthesis. Although there were no interactions among forage and corn sources, the difference in DM digestibility was numerically greater when RS was the sole forage source. Others (Yu et al., 1998; Dhiman et al., 2002; Bernard et al., 2004) have reported no differences in DM digestibility between SFC and GC. Whole-tract di- gestibility of $\mathrm{CP}, \mathrm{NDF}$, and $\mathrm{ADF}$ was similar between energy supplements.

\section{Production Response}

Dry matter intake and production responses for the entire trial are presented in Table 4 . There were no interactions among forage and corn sources, so only main effects are discussed. Average DMI $(P=0.002)$ was greater for BLEND than for RS. This is in agreement with previous research by Burke et al. (2007) in which DMI was greater for animals fed a blend of perennial ryegrass silage $(67 \%)$ and corn silage (33\%) compared with ryegrass silage as the sole forage source. Bernard et al. (2002) did not observe any difference in DMI as RS replaced corn silage at 35,65 , and $100 \%$ of the forage DM.

No differences were observed in milk yield or milk composition among treatments; however, there was a tendency for ECM to be greater for BLEND than RS $(P=0.09)$. This was because of numerically greater milk yield and milk fat percentage for cows fed BLEND compared with RS. Bernard et al. (2002) reported linear

Table 3. Nutrient intake and whole-tract apparent digestibility of lactating cows fed diets containing either ryegrass silage (RS) or a combination of ryegrass and corn silage (BLEND) supplemented with either ground (GC) or steam-flaked corn (SFC)

\begin{tabular}{|c|c|c|c|c|c|c|c|c|}
\hline \multirow[b]{2}{*}{ Item } & \multicolumn{2}{|c|}{$\mathrm{RS}$} & \multicolumn{2}{|c|}{ BLEND } & \multirow[b]{2}{*}{$\mathrm{SE}$} & \multicolumn{3}{|c|}{$P$-value } \\
\hline & GC & $\mathrm{SFC}$ & GC & $\mathrm{SFC}$ & & Forage & Corn & $\begin{array}{c}\text { Forage } \times \\
\text { corn }\end{array}$ \\
\hline \multicolumn{9}{|c|}{ Intake, $\mathrm{kg} / \mathrm{d}$} \\
\hline $\mathrm{DM}$ & 19.65 & 19.63 & 23.55 & 23.04 & 1.0 & 0.006 & 0.45 & 0.46 \\
\hline $\mathrm{OM}$ & 16.02 & 16.59 & 20.05 & 18.78 & 0.86 & 0.002 & 0.69 & 0.30 \\
\hline $\mathrm{CP}$ & 3.72 & 3.66 & 4.39 & 4.03 & 0.19 & 0.13 & 0.28 & 0.42 \\
\hline NDF & 6.02 & 5.94 & 7.08 & 6.66 & 0.30 & 0.008 & 0.40 & 0.57 \\
\hline $\mathrm{ADF}$ & 4.21 & 3.93 & 4.61 & 4.36 & 0.20 & 0.05 & 0.20 & 0.93 \\
\hline \multicolumn{9}{|c|}{ Digestibility, \% } \\
\hline DM & 63.26 & 72.32 & 63.85 & 65.46 & 2.42 & 0.21 & 0.04 & 0.14 \\
\hline $\mathrm{OM}$ & 69.45 & 79.95 & 67.44 & 70.08 & 2.74 & 0.05 & 0.03 & 0.17 \\
\hline $\mathrm{CP}$ & 63.85 & 73.86 & 67.11 & 66.51 & 2.92 & 0.49 & 0.13 & 0.09 \\
\hline $\mathrm{NDF}$ & 50.47 & 55.74 & 47.85 & 44.09 & 2.87 & 0.02 & 0.79 & 0.13 \\
\hline $\mathrm{ADF}$ & 47.87 & 55.85 & 39.02 & 34.73 & 3.58 & 0.002 & 0.92 & 0.21 \\
\hline
\end{tabular}


Table 4. Dry matter intake, milk yield, and milk composition of lactating cows fed diets containing either ryegrass silage (RS) or a combination of ryegrass and corn silage (BLEND) supplemented with either ground (GC) or steam-flaked corn (SFC)

\begin{tabular}{|c|c|c|c|c|c|c|c|c|}
\hline \multirow[b]{3}{*}{ Item } & \multirow{2}{*}{\multicolumn{2}{|c|}{$\mathrm{RS}$}} & \multirow{2}{*}{\multicolumn{2}{|c|}{ BLEND }} & \multirow[b]{3}{*}{$\mathrm{SE}$} & \multicolumn{3}{|c|}{$P$-value } \\
\hline & & & & & & \multirow[b]{2}{*}{ Forage } & \multirow[b]{2}{*}{ Corn } & \multirow{2}{*}{$\begin{array}{l}\text { Forage } \times \\
\text { corn }\end{array}$} \\
\hline & GC & SFC & GC & SFC & & & & \\
\hline DMI, kg/d & 20.3 & 19.2 & 23.0 & 21.7 & 0.5 & 0.0002 & 0.04 & 0.88 \\
\hline Milk, kg/d & 29.6 & 32.0 & 30.0 & 33.1 & 0.8 & 0.35 & 0.004 & 0.66 \\
\hline Fat, \% & 3.46 & 3.10 & 3.71 & 3.11 & 0.28 & 0.68 & 0.10 & 0.68 \\
\hline Fat, kg/d & 1.02 & 0.99 & 1.11 & 1.03 & 0.11 & 0.78 & 0.63 & 0.88 \\
\hline Protein, \% & 2.84 & 2.86 & 2.85 & 2.70 & 0.06 & 0.24 & 0.30 & 0.18 \\
\hline Protein, kg/d & 0.84 & 0.92 & 0.86 & 0.89 & 0.02 & 0.76 & 0.01 & 0.81 \\
\hline $\mathrm{ECM},{ }^{1} \mathrm{~kg} / \mathrm{d}$ & 29.4 & 30.3 & 30.8 & 31.0 & 1.81 & 0.09 & 0.48 & 0.60 \\
\hline Efficiency, Milk/DMI & 1.46 & 1.67 & 1.30 & 1.53 & 0.05 & 0.009 & 0.0005 & 0.76 \\
\hline Efficiency, ECM/DMI & 1.45 & 1.58 & 1.34 & 1.43 & 0.09 & 0.95 & 0.13 & 0.59 \\
\hline MUN, mg/dL & 12.68 & 13.01 & 13.02 & 11.60 & 1.1 & 0.65 & 0.62 & 0.44 \\
\hline BUN, mg/dL & 18.4 & 16.2 & 18.0 & 15.0 & 1.0 & 0.46 & 0.03 & 0.71 \\
\hline Glucose, mg/dL & 55.0 & 56.0 & 56.4 & 57.5 & 1.9 & 0.46 & 0.60 & 0.98 \\
\hline
\end{tabular}

${ }^{1} \mathrm{ECM}=(0.327 \times \mathrm{kg}$ of milk $)+(12.95 \times \mathrm{kg}$ of fat $)+(7.65 \times \mathrm{kg}$ of protein $)$.

increases in ECM as the proportion of RS replacing corn silage in the diet increased. McCormick et al. (1990) observed lower milk fat percentage for cows fed diets based on RS compared with corn silage. Efficiency, defined as kilograms of milk per kilogram of DMI, was greater for RS compared with BLEND (1.57 vs. 1.43, respectively). Milk urea nitrogen, BUN, and blood glucose levels were similar among forage treatments as well.

When diets were supplemented with GC $(21.6 \mathrm{~kg} /$ d), DMI was greater $(P=0.04)$ than when diets were supplemented with SFC $(20.5 \mathrm{~kg} / \mathrm{d})$. No differences in DMI were observed when diets were supplemented with either GC or SFC in previous reports (Yu et al., 1998; Dhiman et al., 2002). The average particle size of GC is smaller than that of SFC, which would allow faster rate of passage for GC, thereby possibly increasing DMI for cows fed GC. Yields of milk $(P=0.004)$ and milk protein $(P=0.01)$ were greater for SFC compared with GC, whereas milk fat percentage $(P=0.10)$ tended to be greater for GC than SFC. Average milk yield was $29.8 \mathrm{~kg} / \mathrm{d}$ for $\mathrm{GC}$ and $32.6 \mathrm{~kg} / \mathrm{d}$ for SFC. The greater $\mathrm{DM}$ and OM digestibility of SFC reflects greater starch digestibility, which should provide more energy for microbial protein synthesis in support of milk production. Improved milk yield with SFC is consistent with previous reports (Santos et al., 1999; Dhiman et al., 2002). The effect of SFC on milk protein yield has been variable. Some researchers (Chen et al., 1994; Dhiman et al., 2002) observed increased milk protein yield, whereas others (Yu et al., 1998; Harvatine et al., 2002) reported no change in milk protein yield when feeding SFC. Presumably, the greater DM digestibility of the SFC diets would allow for greater energy available for microbial protein synthesis and increased milk protein yield. Milk fat percentage averaged $3.56 \%$ for GC com- pared with $3.15 \%$ for SFC $(P=0.10)$. Dhiman et al. (2002) reported that milk fat percentage was reduced on average $7 \%$ when cows were fed SFC compared with finely ground corn. In a review of research on the effects of steam-flaking grain, Theurer et al. (1999) noted that feeding SFC reduced milk fat content by 4 to $5 \%$, but milk fat yield was not altered.

Efficiency, defined as kilograms of milk per kilogram of DMI, was greater for SFC (1.61) compared with GC (1.39). The increase in efficiency was due to the greater yield of milk and lower DMI for the SFC diets. Efficiency of ECM was similar between corn sources. Blood urea nitrogen $(P=0.03)$ was greater for $\mathrm{GC}(18.2 \mathrm{mg} / \mathrm{dL})$ than SFC $(16.6 \mathrm{mg} / \mathrm{dL})$ indicating more efficient use of dietary nitrogen from the forage sources in the SFC diets. Milk urea nitrogen and blood glucose levels were similar among concentrate sources.

\section{CONCLUSIONS}

Results of this trial indicate that feeding a blend of RS and corn silage supports improved performance compared with feeding RS as the sole forage source. The increased milk yield when feeding BLEND can partly be attributed to greater DMI associated with the BLEND. This most likely reflects improved energy from improved whole-tract OM digestibility. Although NDF digestibility was greater for RS, the amount of NDF digested was similar for both RS and BLEND. Steamflaked corn improved performance and efficiency compared with GC. The SFC supported greater DM and presumably starch digestibility, which would have provided additional energy in support of improved microbial protein synthesis and milk production. 


\section{ACKNOWLEDGMENTS}

Partial funding for this project was provided by the Southeast Milk Checkoff. The authors wish to extend their appreciation to Harmon Tawzer and the farm crew for producing and harvesting the forages required for the study, to Sue Trammell and the dairy staff for providing animal care and daily oversight of the trial, and to Melissa Tawzer for assistance with chemical analyses.

\section{REFERENCES}

Association of Official Analytical Chemists. 1990. Official Methods of Analysis. 15th ed. AOAC, Washington, DC.

Bernard, J. K., P. T. Chandler, J. W. West, A. H. Parks, H. A. Amos, M. A. Froetschel, and D. S. Trammell. 2004. Effect of supplemental Llysine- $\mathrm{HCl}$ and corn source on rumen fermentation and amino acid flow to the small intestine. J. Dairy Sci. 87:399-405.

Bernard, J. K., J. W. West, and D. S. Trammell. 2002. Effect of replacing corn silage with annual ryegrass silage on nutrient digestibility, intake, and milk yield for lactating dairy cows. J. Dairy Sci. 85:2277-2282.

Broderick, G. A., R. G. Koegel, R. P. Walgenbach, and T. J. Kraus. 2002. Ryegrass or alfalfa silage as the dietary forage for lactating dairy cows. J. Dairy Sci. 85:1894-1901.

Burke, F., J. J. Murphy, M. A. O’Donovan, F. P. O'Mara, S. Kavanagh, and F. J. Mulligan. 2007. Comparative evaluation of alternative forages to grass silage in the diet of early lactation dairy cows. J. Dairy Sci. 90:908-917.

Chen, K. H., J. T. Huber, C. B. Theurer, R. S. Swingle, J. Simas, S. C. Chan, Z. Wu, and J. L. Sullivan. 1994. Effect of steam flaking of corn and sorghum grains on performance of lactating cows. J. Dairy Sci. 77:1038-1043.

Cochran, R. C., D. C. Adams, J. D. Wallace, and M. L. Galyean. 1986. Predicting digestibility of different diets with internal markers: Evaluation of four potential markers. J. Anim. Sci. 63:1476-1483.

Dhiman, T. R., and L. D. Satter. 1997. Yield response of dairy cows fed different proportions of alfalfa silage and corn silage. J. Dairy Sci. 80:2069-2082.

Dhiman, T. R., M. S. Zaman, I. S. MacQueen, and R. L. Boman. 2002. Influence of corn processing and frequency of feeding on cow performance. J. Dairy Sci. 85:217-226.

Goering, H. K., and P. J. Van Soest. 1970. Forage Fiber Analysis. USDA Agricultural Research Service. Handbook number 379.
US Department of Agriculture. US Government Printing Office, Washington, DC.

Harvatine, D. I., J. L. Firkins, and M. L. Eastridge. 2002. Whole linted cottonseed as a forage substitute fed with ground or steamflaked corn: Digestibility and performance. J. Dairy Sci. 85:1976-1987.

Hoffman, P. C., D. K. Combs, and M. D. Casler. 1998. Performance of lactating dairy cows fed alfalfa silage or perennial ryegrass silage. J. Dairy Sci. 81:162-168.

Keys, J. E., R. E. Pearson, and R. H. Miller. 1984. Effect of ratio of corn silage to grass-legume silage with high concentrate during dry period on milk production and health of dairy cows. J. Dairy Sci. 67:307-312.

McCormick, M. E., E. B. Morgan, T. F. Brown, and A. M. Saxton. 1990. Relationships between silage digestibility and milk production among Holstein cows. Pages 60-64 in Proc. Forage and Grassland Conf. Am. Forage and Grassland Council, Blacksburg, VA.

Moe, P. W., J. T. Reid, and H. F. Tyrell. 1965. Effect of level of energy intake eon digestibility of dietary energy by high producing dairy cows. J. Dairy Sci. 48:1053-1061.

National Research Council. 2001. Nutrient Requirements of Dairy Cattle. 7th rev. ed. Natl. Acad. Press, Washington, DC.

Santos, J. E. P., J. T. Huber, C. B. Theurer, L. G. Nussio, M. Tarazon, and F. A. P. Santos. 1999. Response of lactating dairy cows to steam-flaked sorghum, steam-flaked corn, or steam-rolled corn and protein sources of differing degradability. J. Dairy Sci. 82:728-737.

SAS Institute. 2001. SAS User's Guide. Statistics, Version 8 ed. SAS Inst., Inc., Cary, NC.

Theurer, C. B., J. T. Huber, A. Delgado-Elorduy, and R. Wanderley. 1999. Invited Review: Summary of steam-flaked corn or sorghum grain for lactating dairy cows. J. Dairy Sci. 82:1950-1959.

Van Soest, P. J., J. B. Robertson, and B. A. Lewis. 1991. Methods for dietary fiber, neutral detergent fiber, and nonstarch polysaccharides in relation to animal production. J. Dairy Sci. 74:3583-3597.

Van Vuuren, A. M., A. Klop, C. J. Van Der Koelen, and H. De Visser. 1999. Starch and stage of maturity of grass silage: Site of digestion and intestinal nutrient supply in dairy cows. J. Dairy Sci. 82:143-152.

Van Vuuren, A. M., S. Tamminga, and R. S. Ketelaar. 1990. Ruminal availability of nitrogen and carbohydrates from fresh and preserved herbage in dairy cows. Neth. J. Agric. Sci. 38:499-512.

Van Vuuren, A. M., C. J. Van Der Koelen, H. Valk, and H. De Visser. 1993. Effects of partial replacement of ryegrass by low protein feeds on rumen fermentation and nitrogen loss by dairy cows. J. Dairy Sci. 76:2982-2993.

Yu, P., J. T. Huber, F. A. P. Santos, J. M. Simas, and C. B. Theurer. 1998. Effects of ground, steam-flaked, and steam-rolled corn grains on performance of lactating cows. J. Dairy Sci. 81:777-783. 